International Migration, volume 49, issue 3: pp. 1-9

\title{
The Transnational Political Participation of Latin American and Caribbean Migrants Residing in Europe
}

Jean-Michel Lafleur

\begin{abstract}
Migration from Latin American and Caribbean (LAC) countries to Europe has increased in great proportions over the last decade. Research- ers (principally from southern Europe) have tried to underscore the reasons explaining this phenomenon while also studying different questions related to the presence of these populations such as that of gender, devel- opment, or integration. While many of these works have integrated the transnational dimension of contemporary migration, little has been said so far on the capacity of these migrants to develop transnational political ties and what this means for sending and receiving societies. This publication seeks to address this gap by looking at forms of transnational political involvement as they develop among different LAC communities in different parts of Europe.
\end{abstract}

In recent years, in the context of extension of the European Union and socio-economic transformation of several developing countries, new forms of migration to and within Europe have developed. Simultaneously, the countries of origin of immigrants' to Europe have diversified. Among the new migrants, the number of citizens proceeding from the Latin American and Caribbean (LAC) countries has increased in great proportions.

Indeed, some estimates point out that the LAC population in Europe has moved from around 1 million individuals in 2000 to 2.5 million in [END PAGE 1]

2006. Spain, Portugal and Italy have absorbed the largest share of this new population influx (Lo' pez De Lera and Oso Casas, 2008; Padilla and Peixoto, 2007). However, estimating the size of the LAC population in Europe today with greater precision is rendered difficult by at least three factors. First, the differences in the legal status of those migrants (ranging from high-skilled migrants with specific visa arrangements to undocumented immigrants) create challenges in estimating the total migrant population. Pellegrino (2002) and Poulain (2008) insist that sta- tistics should be taken with great care due to the presence of undocu- mented migrants. Second, some European receiving countries may give preferential access to citizenship to migrants proceeding from LAC countries and therefore render some of these migrants invisible in statis- tics (Tintori, 2009). Third, the 2007 financial crisis has hurt job markets all over Europe, with consequences for the presence of Latin American migrants there that remained to be studied more precisely.

Considering that the United States has been the LAC immigrants' tradi- tional country of destination, the growth of the Latino presence in Europe may appear surprising. Different reasons may explain the increase: the degradation of the countries of origin's socio-economic context, the tightening of the United States' border regulations after the September 11th attacks, and the migration and nationality laws of dif- ferent receiving countries (Lo' pez de Lera and Oso Casas, 2008). Spain, Portugal and Italy have in fact been the largest receivers of new migrants for different historical and cultural reasons (e.g., post-colonial ties, language, etc.), and more traditional push and pull factors (Alonso, 2008; Khoudour-Caste' ras, 2005). In Spain, for instance, it is estimated that the LAC population has multiplied by six between 2000 and 2005

\footnotetext{
* * FRS-FNRS Postdoctoral Research at the Center for Ethnic and Migration Studies, University of Liege, Belgium.
} 
(Vicente Torrado, 2006). For this reason, existing works compiling the experience of LAC immigrants in Europe have traditionally focused on these three receiving countries (see Scarzanella, 2008 and Yepez and Herrera, 2008). However, although they are far more limited in absolute terms, other countries have also experienced large increases in their LAC immigrant population. Their experiences illustrate the diverse experiences of LAC immigrants from one receiving country to the other. Belgium, for instance, has experienced a significant increase in the num- ber of Brazilian migrants coming to work in the construction business in the hope of raising enough money to go back and buy land in their homeland a few years later. This phenomenon has been facilitated by the possibility to obtain tourist visas to Belgium, and the presence of Brazilian middlemen connecting migrants with potential employers (Martiniello et al., 2010). Their experiences obviously differ, however,[END PAGE 2]

from that of Andean women moving to Italy to work as care providers, for example.

Despite the variety of migration experiences of LAC citizens in Europe, different broad themes can be identified in the research on this popula- tion today: the involvement of LAC immigrants in domestic work, the gender and family dimensions of LAC migration to Europe, the sending of remittances and its impact on the home society, the influence of nationality laws on migration flows, and the irregular dimension of LAC migration and its connection with migrants integration in the country of destination. All these research topics share the characteristic that they can be envisaged from a transnational viewpoint looking at the implications of the migrant's life both in the home and host societies.

A dimension that has been surprisingly less covered thus far is the politi- cal involvement of these migrant populations across borders. Reasons for lesser interest in the political dimension of contemporary LAC migration to Europe are unclear. Is it the belief that the transnational dimension of the LAC immigrants in Europe could be rendered more difficult by the longer distance (and associated costs) separating LAC countries from Europe in some cases (in comparison with LAC migrants in the United States)? The fact that studies have been conducted on older politically-driven migrations from South America to Europe seems to discard this hypothesis (Bolzman, 2002; Franco, 2007).

It seems more probable that, just like post-war migrants in Europe had long been envisaged as temporary workers uninterested by politics (Martiniello and Lafleur, 2008), Latin American migrants in Europe have been left out of recent scholarly efforts on migrants' transnational political participation because this migration was thought to be solely economically driven. LAC migrants in Europe were thus far more frequently envisaged as documented or undocumented workers than potential political actors.

The lack of research on the transnational political activities of LAC migrants residing in Europe appears even more surprising if one consid- ers the efforts that Latin American governments have made to strengthen ties with their population abroad. These efforts are visible at three different levels. First, different countries have changed their rheto- ric in addressing their emigrant communities in public discourses. Mexico's President Fox, for example, broke away from the predominant

[END PAGE 3] vision on migration in that country when he called emigrants the coun- try's new heroes after he was elected in 2000 (Martí nez Saldañ a, 2003). Second, while the transformation of this new discourse into concrete policies remains sometimes to be seen, the role of emigrants in their home countries has however been formally acknowledged in many cases. As epitomized by the creation of the National Secretariat for Migration (SENAMI) in Ecuador (see Boccagni's article in this issue), different governments have now set up new public policies or created new agen- cies to strengthen ties with their emigrant communities in the hope of stimulating emigrants' transnational solidarity or facilitating return migration. Again, the feeling of being abandoned by the home country authorities may remain in many cases. However, the development of these policies nonetheless confirms that home countries desire to main- tain ties with the population abroad. Third, different states, including Bolivia, Mexico and Ecuador, have in recent years taken a bigger step in the formal recognition of their emigrants' capacity to remain 
active citizens in the home country by granting them the right to vote from abroad (Lafleur, forthcoming) (with different procedures and different levels of participation as we will show below). Some of these developments and their implications for LAC communi- ties in Europe have been envisaged in recent years. Despite its accent on Spain, the recent edited volume on "Migracio' $\mathrm{n}$ y participacio' n polí tica" by Escriva', Bermú dez and Moraes (2009), for instance, has tried to address these issues by putting in perspective the local and transnational forms of political participation of LAC migrants. Yet, this work also reminds us that migrants' transnational political involvement is not nec- essarily a response to home state invitations to get involved (e.g., by voting from abroad or participating to matching fund programmes). It is indeed more frequently a grassroots political mobilization that has trans- national political implications.

This last element encouraged us to adopt for the purpose of this special issue a rather broad definition of immigrant political transnationalism, such as the one adopted in previous works: Immigrant political transnationalism covers any political activity under- taken by migrants who reside mainly outside their homeland and that is aimed at gaining political power or influence at the individual or col- lective level in the country of residence or in the state to which they consider they belong. Such power or influence may be achieved by interacting with all kinds of institutions (local, subnational, national or [END PAGE 4] international) in the country of residence andor the home country, by supporting movements that are politically active in the country of ori- gin or by intervening directly in the country of origin's politics. When analysing political power in the country or countries of residence, one may speak of immigrant political transnationalism when the activities are conducted by migrants of the same national origin but residing in different destination countries or when the state authorities of the send- ing country interfere with their emigrants' activities in the country of residence (Lafleur and Martiniello, 2009).

In this special issue, we propose to pursue the effort started by Escriva' Chorda et al. (2009) in two respects. First, we include contributions on migrant communities in the three main destination countries (Spain, Portugal, and Italy) but also concerning other European countries (Switzerland, the United Kingdom, and the Netherlands). This allows us to provide a clearer picture of the LAC population in Europe by under- lining the differences and similarities in the migrants' profile, but also in their political practices across different countries of destination. Simi- larly, this broader comparison will contribute to the debate on the simi- larities and differences between immigrant transnational practices in Europe and the United States (see Lafleur and Martiniello, 2009). Secondly, this special issue seeks to reach a balance between migrant communities that are the most significant in numerical terms in Europe (Ecuadorians and Peruvians) and other groups who have attracted less academic interest in recent years (Colombians, Mexicans, Chileans, and Surinamese) but whose political practices nevertheless highlight the ongoing political relationship between emigrants and their home coun- tries. In this sense, this special issue contributes to the ongoing theoreti- cal debate on transnationalism by approaching disputed questions while also underscoring the diversity in this heterogeneous group of LAC immigrants in Europe. Indeed, many of the questions that are currently at stake in the research on immigrant political transnationalism will be discussed in this publica- tion. Three papers explore, with different approaches, the question of how globalization is reshaping emigrant citizenship in the twenty-first century. Beatriz Padilla discusses how host and home states have gained interest in issues of migration and how this potentially creates complex situations for migrants trying to secure citizenship in both spaces. Based on her analysis of Brazilians in Portugal, she also demonstrates how the development of home state policies towards emigrants is related to the [END PAGE 5] state's desire to gain influence at the global level. In her discussion on the linkages between migration and co-development policies involving Ecuadorian migrants, Almudena Cortes develops a similar argument by showing how Spanish authorities use codevelopment to position them- selves in the global arena. In doing so, she stresses the existence of new modes of governance in which the management of migration by the State integrates a larger number of stakeholders both in Spain and Ecuador. Liza Mü gge replaces the development of transnational political activities in the framework of the Dutch-Surinamese postcolonial con- text and shows how ethnicity and religion are crucial structuring princi- ples in 
Surinamese political transnationalism that undermine forms of transnationalism geared towards Surinamese society or the Surinamese state as a whole.

Two other papers focus on a specific type of migrant's political involve- ment in the home country, external voting, and its meaning and impact on home societies. Paolo Boccagni's analysis of Ecuador's external vot- ing experience reveals the contradictions between the home state's motivation to grant external voting rights on the one hand, and the motivation for voters abroad to participate. His thorough fieldwork among Ecuadorian immigrant voters in Italy contributes to the discus- sion on the long-term viability of such mechanisms and questions the relations between voting from abroad and other forms of transnational involvement. Lafleur and Calderon Chelius, in turn, examine in detail the 2006 Mexican Presidential election that allowed emigrants to vote from abroad for the first time. Building on a discussion on the migrants' interest in voting in the home country and on the role of bureaucratic barriers, they more generally try to identify variables that explain turn- out among emigrant voters.

A third set of papers focus on migrant agency and how the local context might influence specific forms of transnational political activities. AnastasiaBermudez, in her paper on

Colombians in the United Kingdom and Spain, examines the role emigrants can play in political conflicts at home. In her empirical approach to these understudied com- munities, she combines migrants' perception of the conflict at home with a discussion on the potentialities and limitations of migrant involvement in the search for peace. Claudio Bolzman's approach differs in the sense that he looks at the historical evolution of Chileans' involvement in home country politics hypothesizing a move from a situation of political exiles to that of transnational political activists. Similarly, this scholar shows how Chileans in Switzerland have been capable of mobilizing for [END PAGE 6] host state political issues thanks to the political capital accumulated dur- ing their years as exile activists. A last paper by Guido Tintori focuses on the somewhat specific issue of Latin American citizens who have recently acquired Italian citizenship (thanks to preferential legislation) in great numbers and have consequently become potential voters in Italy. This paper thus identifies the outputs and outcomes from the transna- tional political practices of "Latin American Italians", both in Italy and the countries of residence, and how these have created overlapping polities, affected the conception of membership, and challenged the definition of "home" and "host" country. As we underscored in this brief introduction, this publication seeks to shed light on the political practices of a population which, despite its growing proportion among new migrants in Europe, has not been very much studied. In addition to its thematic originality, this special issue will also bring a contribution to conceptual discussions on immigrant political transnationalism due to the comparative dimension it opens with similar work conducted in North America.

\section{ACKNOWLEDGEMENTS}

This publication has been possible thanks to the support of the research cluster on Migration and Citizenship of the European Network of Excel- lence on International Migration, Integration and Social Cohesion in Europe (IMISCOE) and the support of the Belgian Political Science Association (ABSP-CF). I also wish to thank Jehan Balba, Rainer Baubo"ck, Hassan Bousetta, Luis Garzó n, Elzbieta Gozdziak, Marco Martiniello, Laura Morales, Nathalie Perrin, Wiebke Sievers, Francesco Tarantino and all anonymous reviewers at International Migration for their respective contributions at different stages of this publication project.

REFERENCES

Alonso, J.A. 2008 "Destino, España: Tribulaciones de una Joven Potencia Migratoria", Foreign Affairs en Español, 8(2): 37-50 (in Spanish). Bolzman, C. 2002 "De l'exil a' la diaspora. L'exemple de la migration chilienne", Autrement, (22): 91-107 (in French). [END PAGE 7]

Escrivá Chorda, A., A. Bermú dez, and N. Moraes 2009 Migració n y participació n polí tica: estados, organizaciones y migrantes Latino Aamericanos en perspectiva local-transnacional, Consejo Superior de 
Investigaciones Cientí ficas, Madrid (in Spanish).

Franco, M. 2007 "Les Argentins et la France des anné es 1970. Droits de l'homme et solidarite'", Revue Hommes et Migrations, (1270): 20-31 (in

French). Khoudour-Casteras, D.

2005 "Causes and implications of the current mass emigration process in Latin America",

Alternativas: Cuadernos de Trabajo Social, (13): 113-134.

Lafleur, J.-M. forthcoming "Why do states enfranchise citizens abroad?: Comparative

Insights from Mexico, Italy and Belgium", Global

Networks. Lafleur, J.-M., and M. Martiniello

2009 "Towards a transatlantic dialogue in the study of immigrant polit- ical transnationalism", in J.-M.

Lafleur and M. Martiniello (Eds), The Transnational Political Participation of Immigrants. A transat-

lantic Perspective, Routledge, Abingdon.

Lo' pez De Lera, D., and L. Oso Casas 2008 'L'immigration latino-amé ricaine en Espagne.

Tendances et é tat

de la question", in I. Yepez and G. Herrera (Eds), Nouvelles Migrations Latino-Amé ricaines en

Europe. Bilans et Dé fis, Obreal, Barcelona (in French).

Martí nez Saldañ a, J. 2003 "Los Olvidados become heroes: the evolution of Mexico's policies

towards citizens abroad", in E. Østergaard-Nielsen (Ed.), Interna- tional Migration and Sending

Countries, Palgrave Macmillan, Houndsmills.

Martiniello, M., and A. Rea et al. 2010 Nouvelles Migrations et Nouveaux Migrants en Belgique,

Academia

Press, Gent (in French). Padilla, B., and J. Peixoto

2007 Latin American Immigration to Southern Europe, Migration Information, available at

http://www.migrationinformation.org/ Feature/display.cfm?id=609.

Pellegrino, A. 2002 "Skilled labour migration from developing countries: study on

Argentina and Uruguay", International Migration Papers, 58: 1-28. Poulain, M.

2008 "La pré sence latino-amé ricaine en Europe: Les donne' es statis- tiques", in I. Yepez and G.

Herrera (Eds), Nouvelles Migrations Latino-Amé ricaines en Europe, Obreal, Barcelona (in French).

[END PAGE 8

]Scarzanella, E. 2008 "Latin America: migrants, nations and identities", Studi Emigrazi-

one, XLV(170): 265-392. Tintori, G.

2009 Fardelli d'Italia. Conseguenze Nazionali e Transnazionali delle Poli- tiche di cittadinanza italiane, Carocci, Rome (in Italian).

Vicente Torrado, T.L. 2006 La Inmigración Latinoamericana en Espan`a, Population Division

Department of Economic and Social Affairs, United Nations Sec-

retariat, Mexico City (in Spanish). Yepez, I., and G. Herrera

2008 Nouvelles Migrations Latino-Amé ricains en Europe, Obreal, Barcelona (in Spanish).

[END PAGE 9] 